\title{
The Principle of Individuation in Contra Eunomium 2, 4 by Basil of Caesarea and Its Philosophical and Theological Context
}

\author{
Dmitry Biriukov \\ National Research University Higher School of Economics (HSE), Research \\ Nuclear University MEPhI, Saint Petersburg State University of Aerospace \\ Instrumentation, Saint Petersburg, Russia \\ dbirjuk@gmail.com
}

\begin{abstract}
The article analyzes the context of describing the human being through the "concurrence of properties" in the Contra Eunomnium 2.4 of Basil of Caesarea and traces the links of this topic in Basil with the theories of individuation current in Antiquity. The continuity of Basil's teaching of the concurrence in the analyzed passage with the On Prayer 24 of Origen, which reveals some Stoic connotations, is examined. At the same time, the article points to the difference between Basil's and Origen's conceptual frameworks. Two paradigms of understanding the material substratum in Basil - Platonic and Stoic - are identified. The article demonstrates the direct Stoic influence on the analyzed passage of Basil and specifies what it consisted of and why exactly Basil used the Stoic paradigm. Then, based on the place from the Apology of Eunomius, which Basil was refuting in his passage, the article reveals both the context of the passage and of the place in Eunomius in a wider setting of the doctrines of language elaborated in Antiquity.
\end{abstract}

\section{Keywords}

individuation - hypostasis - substance - Arian controversy

* The present study is a part of a larger project № 16-18-10202, "History of the Logical and Philosophical Ideas in Byzantine Philosophy and Theology", implemented with a financial support of the Russian Science Foundation. 
The writings important for the history of the Patristic thought and for the history of philosophy as a whole contain some key texts which are crucial for several lines of further development of thought. I would like to focus on one of these texts from the writings of Basil of Caesarea. This passage can be found in the beginning of the second book of Basil's Contra Eunomium. ${ }^{1}$ Arguing with the doctrinal positions of the Apology, ${ }^{2}$ written by the Neo-Arian (Anomoean) leader Eunomius who insisted on a rigid relationship between the name of an individual and his substance, Basil comes to distinguishing between the general substance and the particular properties, united by the name:

But what sane person would agree with this logic that there must be a difference of substances for those things whose names are distinct? For the designations of Peter and Paul and of all people in general are different, but there is a single substance for all of them. For this reason, in most respects we are the same as one another, but it is only due to the distinguishing marks considered in connection with each one of us that we are different, each from the other. Hence the designations do not signify the substances, but rather the distinctive features that characterize the individual. So whenever we hear 'Peter,' the name does not cause us to think of his substance - now by 'substance' I mean the material substrate which the name itself cannot ever signify - but rather the notion of the distinguishing marks that are considered in connection with him is impressed upon our mind. For as soon as we hear the sound of this designation, we immediately think of the son of Jonah, the man from Bethsaida, the brother of Andrew, the one summoned from the fishermen to the ministry of the apostolate, the one who was charged with the building up of the church because of the superiority of his faith. None of these is his substance, understood as hypostasis. Hence the name ( $\tau \dot{\text { ò }}$ ovo $\mu \alpha)$ determines for us the character of Peter. It cannot ever communicate the substance itself. Likewise, when we hear 'Paul,' we think of a concurrence of the other distinguishing marks: the man from Tarsus, the Hebrew, as to

1 Concerning the date of the Contra Eunomium, there is an agreement that it was written in the beginning of the theological activity of Basil, that is, in the first half of the 360 . The most cautious scholars attribute the treatise to the period between 360 and 366 . The exact date of the treatise is based on the date of two letters of Basil (Epistulae 20 and 223), which contain references to it (S. Hildebrand, "A Reconsideration of the Development of Basil's Trinitarian Theology: the Dating of Ep. 9 and 'Contra Eunomium,'” vc, 58 (2004), pp. 390-403).

2 The Apology of Eunomius was probably written by the time of the Council of Constantinople, held in December, 359, and was read at the Council in response to the accusations made by the representatives of the Homoiousian party [Th. Kopecek, A History of Neo-Arianism, vol. 2 (Patristic Monograph Series of the North American Patristic Society, 8), Cambridge, MA, 1979, pp. 305-306]. 
the law a Pharisee, the disciple of Gamaliel, the zealous persecutor of the churches of God, the man who was brought to knowledge by a terrifying vision, the Apostle to the Gentiles. All these things are encompassed by the single term Paul.

Moreover, if it were true that the substances of things whose names differ are opposed, then Paul and Peter and all people in general must be different in substance from one another. But there is no one so stupid and so inattentive to the common nature that he would be led to say this after all, the passage: You have been formed from clay, as also have [Jb 33:6 ] signals nothing other than that all human beings are of the same substance. This being the case, whoever evasively argues that difference in substance follows upon difference in names is a liar.

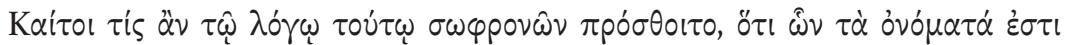

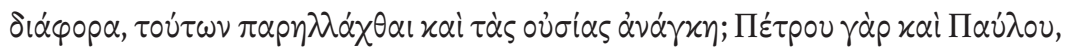

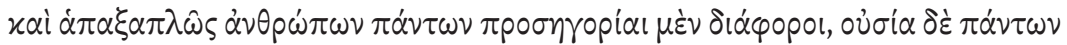

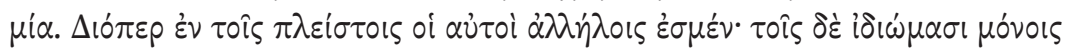

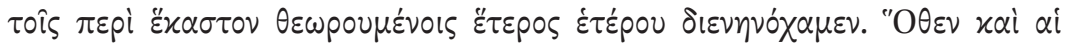

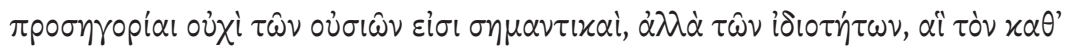

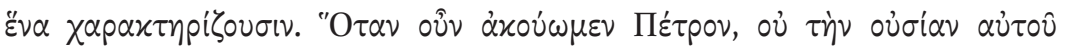

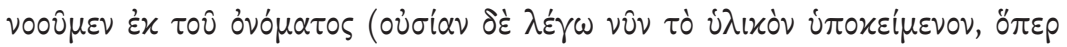

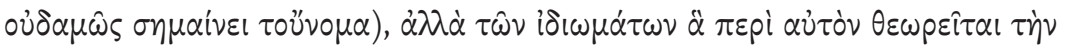
हैंv

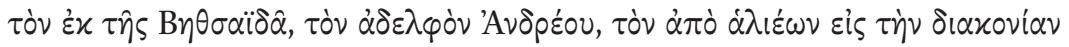

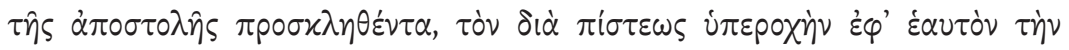

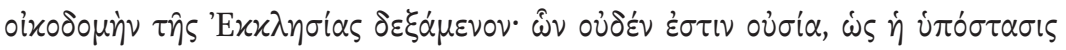

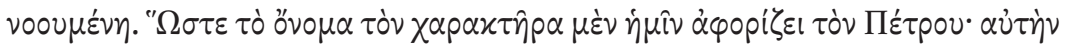

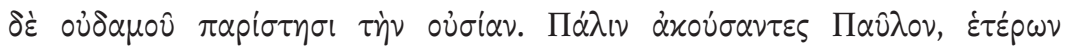

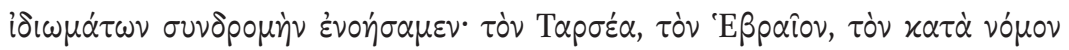

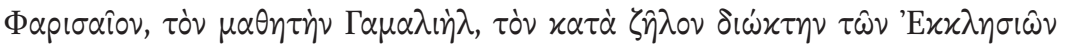

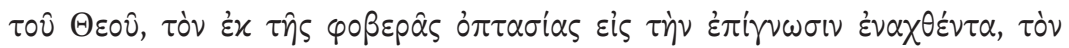

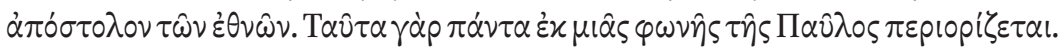

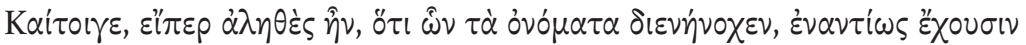

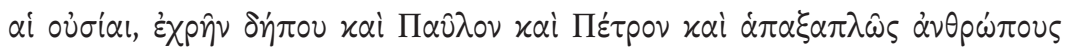

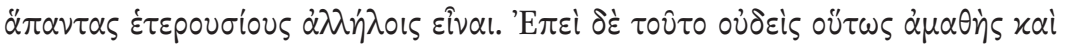

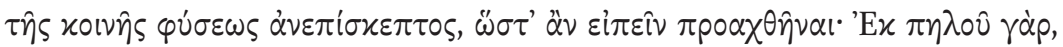

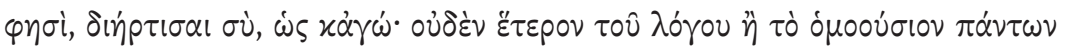

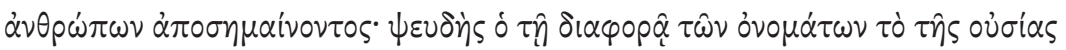

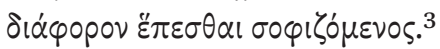

3 Contra Eunomium, 2,4 (PG 29, col. 577c-58ob; SC 305, 18-22 Sesboüé/Durand); St. Basil of 
Further Basil went on to say the relationship between the names of the Divine Persons and their common substance needed to be understood in the same way as the relationship between Peter and Paul and their common substance. A. Choufrine has shown ${ }^{4}$ that it was this passage that Gregory of Nyssa used in the so-called Letter 38 of Basil of Caesarea. The Letter, currently attributed by most scholars to Gregory of Nyssa, ${ }^{5}$ reinforced and developed the analogy invented by Basil, and illustrated the notion of generality and differences between the hypostases of the Holy Trinity, drawing on the example of human individuals. ${ }^{6}$

Let us identify the scope of the problems discussed in the passage. They include the relationship between the general and the particular, the problem of human cognition and the object of cognitive activities, the status of naming, as well as description and representation of a human individual. This article analyzes the position of Basil of Caesarea concerning these problems as well as some other philosophical and theological topics against a wide philosophical, theological and ecclesiastical background of the fragment quoted above.

The principle of individuation is one of the most important problems addressed in the passage. Basil solves it through the use of the concept of con-

Caesarea, Against Eunomius, trans. by M. DelCogliano and A. Radde-Gallwitz (The Fathers of the Church, 122), Washington, 2011, pp. 134-136, slightly revised.

4 A. Choufrine, "The Development of St. Basil's Idea of 'Hypostasis," Studi sull'Oriente Cristiano, 7 (2003), pp. 22-24.

5 See, for example, the conclusions of R. Hübner and P. Fedwick in R. Hübner, "Gregor von Nyssa als Verfasser der sog. Ep. 38 des Basilius: Zum unterschiedlichen Verständnis der ousia bei den kappadokischen Brüdern," in: Epektasis: Mélanges patristiques offerts au cardinal Jean Daniélou, eds. J. Fontaine, Ch. Kannengiesser, Paris, 1972, pp.463-49o; P. Fedwick, "Commentary of Gregory of Nyssa on the 38th Letter of Basil of Caesarea," OCP, 44 (1978), pp. 31-51; for the almost definitive conclusion, s. G. Maspero, M. Degli Espositi, D. Benedetto, "Who Wrote Basil's Epistula 38? A Possible Answer through Quantitative Analysis," in: Gregory of Nyssa Contra Eunomium III. An English Translation with Commentary and Supporting Studies. Proceedings of the 12th International Colloquium on Gregory of Nyssa (Leuven, 14-17 September 2010), eds. J. Leemans, M. Cassin, Leiden-Boston, 2014, pp. 579-594. There is little doubt that the so-called "Letter 38 " was written by Gregory of Nyssa later than the Contra Eunomium of Basil of Caesarea.

6 Epistula 38.3 ; $P G$ 32, col. $328 \mathrm{~cd}$. The notion of a certain specific quality set in accordance with hypostasis, which was used in the Letter 38 and implied in the above passage of Basil of Caesarea (who in this case did not use the concept of hypostasis in the technical Nicaean sense), goes back to the Homoiousians (Basil Ancyra and George Laodicean), see Epiphanius, Panarion, 73.16 ( $P G$ 42, col. 432-433). 


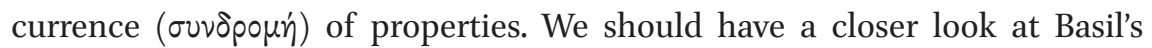
argument and first turn to the doctrine of the Stoics.

When the head of the Skeptic Academy Arkesilaos made a stand against the Stoics, one of the stumbling blocks was the so-called Treatise on Growth (Пвpi

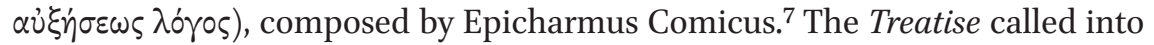
question the sameness of an individual who was undergoing the process of quantitative changes, for example, during food intake. In contrast to the understanding of a human being as a whole which was identical to the sum of its parts and whose principle of individuation was the amount of matter, ${ }^{8}$ the Stoic Chrysippus proposed a concept which for the first time as David Sedley noted, ${ }^{9}$ made an attempt to answer the question of what made it possible for a person to carry his or her identity throughout the flow of time. Specific Stoic position on the issue was shaped by two factors: firstly, by the obvious identity of a human individual throughout his life, and secondly, by the Stoic epistemology which rejected the skepticism of the followers of the Academy and proclaimed that every true sage was capable of receiving unmistakable "comprehensive impressions." ${ }^{10}$

Insisting on the capacity to know the individuals, the Stoics argued that each thing was unique, and no two indistinguishable things existed (at least, for a sage). In this regard, in a human being Chrysippus distinguished between the underlying substrate which was in constant change, and the constant qualities - the general quality and the particular individual quality (iסi $\omega \varsigma$ soióv), peculiar for each human being and serving as his substantial characteristic. This quality made it possible for an individual human being to maintain same-

7 DK 23 B 2; Die Fragmente der Vorsokratiker, eds. H. Diels, W. Kranz, vol. 1, Berlin, 1960, pp. 195-197.

The doctrine of Heraclitus presents here an obvious philosophical context (see DK 22 B 91; Die Fragmente der Vorsokratiker, S. 171). The doctrine of the constant transiency of humanity as far as his material component is concerned, can be also found in Plato (Symposium, 207de). Plato mentions Epicharmus as a philosopher who, along with Protagoras, Heraclitus, Empedocles, and Homer taught on the constant flux of the material world (Theaetetus, 152e). Despite this reference, Plato was accused by Alcimus of stealing ideas from Epicharmus (see Diogenes Laertius, 3.9-10). However, the problem of finding the principle of identity for the humans as material beings, implicit in the comedy of Epicharmus, was not a central issue in philosophical inquiries of Plato or Aristotle. Only in the controversy between the Stoics and the Academy, the problem of the human identity became the main issue of the philosophical research (D. Sedley, "The Stoic Criterion of Identity," Phronesis, 27 (1982), pp. 255-275, here p. 255). 
ness and stability during the lifetime in spite of the flow of time. ${ }^{11}$ According to Chrysippus, it could be formalized and expressed in the language. We should note that the notion of the particular quality in the Stoic system was developed for safeguarding the individuality of human beings, and not of individual things in general. ${ }^{12}$

Although according to the Stoics the particular quality of an individual human "remained from birth to death," it nevertheless had a capacity to increase and decrease. ${ }^{13}$ Thus, having established the differentiation of the levels of being in the description of an individual and having distinguished between the substrate and the special unique quality of an individual accessible for knowledge, Chrysippus proposed an original solution for his time: an individual was unconfused yet indivisible unity of ever-moving material substrate and the particular individual quality, stable over the lifetime. It is important that the Stoics insisted that the particular quality could not be the same for several individuals (this followed from the general principle of the Stoic philosophy, namely, that no two things indistinguishable from each other may exist), and vice versa - one individual cannot have two particular qualities. ${ }^{14}$

This doctrine of general quality and particular qualities was reflected in the Stoic teaching on the parts of speech. According to Diogenes Laertius, Chrysippus distinguished between the proper name (ovo $\mu \alpha)$ and the appellative name ( $\pi$ poonropía). Chrysippus' student Diogenes of Babylon gave them the following definition, "The appellative name ( $\pi p \circ \sigma \eta \gamma o p i \alpha)$ is the part of speech denoting general quality ( «oเvทे $\pi 010$ ' $\eta \tau \alpha$ ), for example, 'man' or 'horse'. The proper

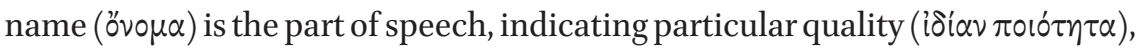
for example, Diogenes or Socrates." ${ }^{15}$

11 See I. von Arnim, Stoicorum Veterum Fragmenta, Stuttgart, 1903 [repr. 1964], vol. II, fr. 395, p. 762 .

12 Sedley, The Stoic Criterion, p. 272, n. 16.

13 See Plutarch, De communibus notitiis, 44, 1083d; Posidonius, fragm. 96: LS 28D (A. Long, D. Sedley, The Hellenistic Philosophers, Cambridge, 1987, vol. 2, p. 171).

Although Plutarch criticized the Stoics that according to their doctrine, "two particular qualities may appear in one substance, and... one and the same substance that has one particular quality then takes over another [particular quality] and keeps both" (Plutarch, De communibus notitiis, $36,1077 \mathrm{~d}$ ), this conclusion in no way would have been shared by the Stoics, but was ascribed to them by Plutarch, allegedly as a result of their belief in the world fire, when Zeus and the Providence come close and coexist in the same ethereal substance. In fact, the Stoic concept that Providence has the same relation to Zeus as the soul relates to the person, mentioned by Plutarch in the same passage, contradicts his opinion (Sedley, The Stoic Criterion, p. 267).

15 Diogenes Laertius, 7,58 = I. von Arnim, Stoicorum Veterum Fragmenta, Stuttgart, 1904 [repr. 1964], vol. III, fr. 22. 
Such a distinction between the proper names and the appellative names was used by the Alexandrian grammarians. At the same time, sources indicate that there were two traditions of defining obvo $\mu \alpha$ and $\pi p o \sigma \eta \gamma o p i \alpha$. If Apollonius Dyscolus and the subsequent tradition correlated ${ }^{16}$ them with particular and general qualities of the denotation of utterance, Dionysius of Thrace and his grammatical tradition ${ }^{17}$ correlated them with general and particular substanc$e s$, which can be associated with the Aristotelization of the Alexandrian grammar. $^{18}$

Based on the evidence of some of the later sources, it can be assumed that the Stoics could understand the particular quality as a combination of qualities. The surviving testimony of Dexippus on the principle of individuation of individuals belonging to the same substance, is as following:

$<\ldots>$ Those who solve this difficulty on the basis of the peculiarly qualified - that one individual is distinguished, say, by hookedness of the nose, by blondness, or by some other concurrence of qualities, another by snubness, baldness, or greyness of the eyes, and again another by other qualities - do not seem to me to solve it well.

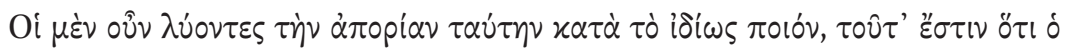

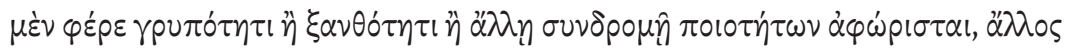

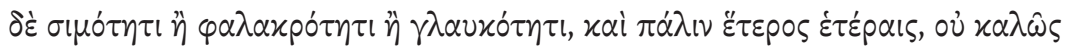

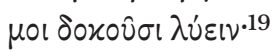

A. Long and D. Sedley saw the employment of the Stoic terminology in the use of qualities in the passage and considered the fragment to be a testimony on the Stoic ontology. ${ }^{20}$ Yet, they pointed out to a strange nature of the fragment, since the substantial status of the particular quality sought by the Stoics, seems

16 See, for example, Apollonii Dyscoli de constructione libri quattuor, ed. G. Uhlig (GG, 2,2), Leipzig, 1910, pp. 142.1-143.3; Scholia in Dionysii Thracis Artem grammaticam, ed. A. Hilgard (GG, 3.1), Leipzig, 1901, pp. 358.28-32, 524.9-10.

17 Dionysii Thracis Ars grammatica, ed. G. Uhlig (GG, 1.1), Leipzig, 1883, pp. 33.6-34.2; Georgii Choerobosci Prolegomena et scholia in Theodosii Alexandrini canones isagogicos de flexione nominum et verborum, ed. A. Hilgard (GG, 4.1), Leipzig, 1894, p. 105.23-25.

Cf. D. Robertson, "A Patristic Theory of Proper Names," Archiv für Geschichte der Philosophie, 84 (2002), pp. 1-19, here p. 3.

19 In Aristotelis categorias commentarium, 30.23-26; Greek text in: Long, Sedley, The Hellenistic Philosophers, vol. 2, pp. 173-174 (LS 28J), trans. by A. Long and D. Sedley, The Hellenistic Philosophers, vol. 1, p. 169, slightly revised.

20 Long and Sedley published the fragment in the section of the Ontology (ibid., pp. 166185). 
to be somewhat in the fragment since these general qualities may change during the life of an individual. ${ }^{21}$

However, there is a number of reasons confirming the suggestion that the fragment of Dexippus, referring to the unfolding of the particular quality through the combination of general qualities, may still reflect the authentic Stoic doctrine. Thus, as A. Lloyd rightly observed, according to the Stoic doctrine of the categories, the particular quality of a person can be viewed as a complex set of qualities. ${ }^{22}$ Lloyd had in mind the normative principle of the Stoic doctrine - viewing the subject from several points of view with the help of four Stoic categories, each one revealed by the following category. In the run of this process of consideration, the subject was being identified progressing from a lesser certainty to a greater certainty, and from the point of view of nonrelativity (corresponding to the category of the substrate) to the point of view which revealed all kinds of relationships between the subject and the world (corresponding to the category of relation).

It remains unclear whether it is possible to assume that the Stoic tradition made its way from the understanding of the particular quality as capable of increase or decrease (that is, of change) to the description of the particular quality through a set of qualities. However, we may definitely see a clear difference in emphasis - in the latter case much more emphasis is put on the epistemological function of the particular quality of an individual and the possibility of determining the particular quality in the process of knowledge.

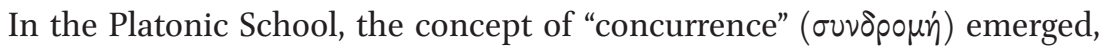
on the one hand, in the skeptical "New Academy" for expressing the need to have a multitude of true notions in order to obtain a single true notion of a sensible thing (including an individual human being). For example, according to Carneades, our notion of Socrates would be true if each of the notions related to Socrates and converged into a singularity really pointed to something typical for Socrates. ${ }^{23} \mathrm{On}$ the other hand, this topic is relevant to the method of defining material things through aggregation $\left(\tau \dot{\partial} \alpha \theta_{\rho} \circ \diamond \sigma \mu \alpha\right)$ of qualities, which goes back to Plato ${ }^{24}$ and can be found, for example, in Albinus. ${ }^{25}$ In Plotinus, the topic of concurrence appears in the Enneads VI 3. 8. 20, 26, where the phi-

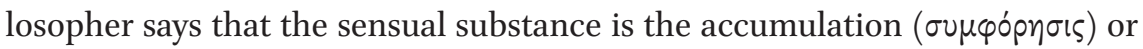

\footnotetext{
21 Ibid., vol. 1, p. 174; vol. 2, pp. 174-175.

22 A. Lloyd, "Grammar and Metaphysics in the Stoya," in: Problems in Stoicism, ed. A. Long, London, 1971, pp. 58-74, here p. 66.

23 Sextus Empiricus, Adversus mathematicos, 7, 176-179.

24 Theaetetus, 157b-c; cf. ibid., 209c; Philebus, 14a, 15b.

25 Albinus (Alcinous), Epitome, 4,7.
} 
mixture $(\mu i \gamma \mu \alpha)$ of qualities. Typically, speaking about substance as a combination of qualities Plotinus along with the entire Platonic tradition intends to show that the sensual singular substance is a "quasi substance," a substance not in the proper sense of the word, but only an imitation of the true intelligible substance. ${ }^{26}$

However, the notion of the concurrence of properties in Basil of Caesarea may be well related to the treatment of same topic by Porphyry, since among the other philosophers of the Platonic tradition it was Porphyry who applied the topic of concurrence (aggregation) of qualities in his logical writings for describing a human individual.

In his logical treatises Porphyry at least twice mentioned individuation of singularities through the aggregation of qualities. He dwelled on the subject in greater length in the Isagoge and more briefly in his Short Commentary on Aristotle's Categories. Thus he argues in the Isagoge:

Socrates is said to be an individual, and so are this white thing, and this person approaching, and the son of Sophroniscus ${ }^{27}$ (should Socrates be his only son). Such items are called individuals because each is constituted of proper features the assemblage of which will never be found the same in anything else - the proper features of Socrates will never be found in any other of the particulars.

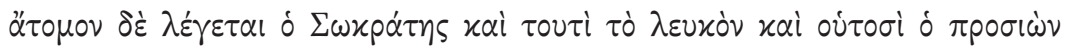

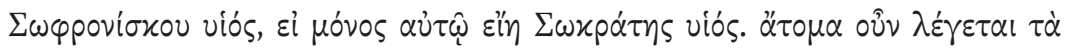

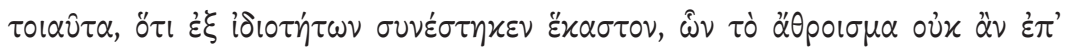

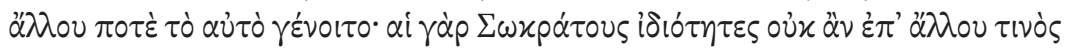

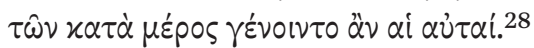

In the treatise On Aristotle categories, Porphyry uses the concept of the "concurrence" ( $\sigma u v \delta \rho \circ \mu$ ') of qualities with similar wording:

26 See Enneades, 6,3,8,30-37, cf. 6,3,15,32-36.

27 With respect to the words, "....and this approaching, and the son of Sophroniscus" I am following the reading of J. Barnes (Porphyry, Introduction, trans., and comm. J. Barnes, Oxford, 2003, p. 8), whereas the reading in the classic edition of A. Busse is as follows, “... and this approaching son of Sophroniscus." For more detail, see F. Ademollo, "Sophroniscus' Son is Approaching: Porphyry, Isagoge 7.20-1," The Classical Quarterly, 54 (2004), pp. $322-325$. In addition to the textual arguments in favor of his reading, Barnes points to an important example in a work of Aristotle (Aristotle, Analytica Priora, 43a35-6), which probably was the source of Porphyry.

28 Porphyrius, Isagoge, 7,19-24 (Busse), trans. by J. Barnes: Porphyry, Introduction, p. 8. 
Socrates does not differ from Plato in virtue of specific differentiae, but in virtue of a particular concurrence of qualities, in virtue of which, and $<$ not $>$ by specific differentiae, Plato is differentiated from Socrates.

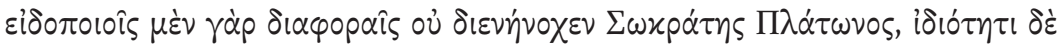

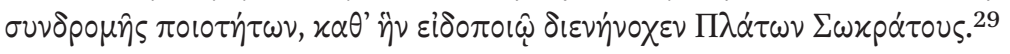

In his logical treatises Porphyry tried to neutralize the anti-Platonic stance of Aristotle's Categories and therefore insisted on understanding the Aristotelian Categories as a treatise on the methods of expression and not on the modes of existence of things, ${ }^{30}$ implying that this treatise described only the reality of the thought or the reality of the logical reasoning.

Relying on his tree of the universals, Porphyry distinguished between the predicates in accordance with the expanse of classes, comprised by the predicates: the highest genus was said of all underlying genera; the lower genera were said of the genera below them, etc. Such a system had a rule: each predicate was said either of something wider than itself or of something identical to it in extension. The lowest class of predicates which can only be said of them-

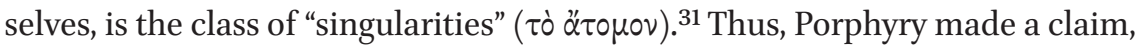
impossible for Aristotle, that the singularity itself was a predicate. ${ }^{32}$ According to Aristotle, individual qualities of a thing were within the subject, but were not said of the subject. ${ }^{33}$ Porphyry, however, accepted that the single could be expressed in the saying in the same way as the higher elements in the genusspecies tree. Facing the need to specify a "zero" class, corresponding to the singularity of the species, which would have required a simple pointing with finger, Porphyry proposed to consider the singularity as if from the reverse side for expressing this specificity in thought and language. He suggested looking at the singularity not through the prism of genus-species relationships, but through the unique aggregation of qualities. In order to express these singularities in saying, Porphyry modified the above rule: certain predicates could be said of each of the singularities; the aggregation of predicates was unique for

29 Porphyrius, In Aristotelis categorias expositio, 129,9-10 (Busse), trans. by S. Strange: Porphyry, On Aristotle's Categories, Ithaca - New York, 1992, p. 140.

30 Ibid., p. 58,4-21.

31 Porphyrius, Isagoge, 7,18-19.

32 See A. Lloyd, The Anatomy of Neoplatonism, Oxford, 1990, pp. 43-44.

33 Aristoteles, Categories, 1a23-29. 
each singularity, and that aggregation constituted a sort of definition for the given singularity. ${ }^{34}$

Going back to the testimony of Dexippus, we can point out that there is an evidence that Porphyry could use the Stoic doctrines in his logical writings. ${ }^{35}$ Therefore, it can be assumed, as R. Chiaradonna does, ${ }^{36}$ that Dexippus combined Porphyry's concept of singularities with the Stoic doctrine of the particular quality, arguing with Porphyry and bearing in mind the influence of the elements of the Stoic doctrine on him, but not willing to criticize Porphyry directly. Dexippus could also have in mind that Aristotle, the author of the Categories (the writing which Porphyry comments upon in his Isagoge), criticized the way of individuation through the combination of qualities. ${ }^{37}$

Among the Christian writers Origen was the predecessor of Basil of Caesarea as far as the description of an individual through the combination of qualities is concerned. R. Sorabji pointed to the passage of Origen, ${ }^{38}$ which probably was behind Basil's idea to use the example that he cited in the fragment under discussion, namely, On Prayer 24:

A proper name then is a concise appellative that presents the distinctive quality of what is named, for example, there is a distinctive quality of the Apostle Paul, one for his soul by which it is the way it is, one for his intellect by which it can contemplate the kinds of thing it does, one for his body by which it is the way it is. The unique feature which is unconformable with anyone else, since there is no one else in existence indistinguishable from Paul, is displayed through the naming of Paul. But with

34 See the discussion in the comments of J. Barnes to the Isagoge: Porphyry, Introduction, pp. 150-154.

The Stoic influence on Porphyry was noted by Simplicius in his Commentary on the Categories $(2,8-9)$. Explicit Stoic connotations can be traced in the passage of Porphyry, which Simplicius cited in the same work (Ibid., 48,11-16).

36 R. Chiaradonna, "La teoria dell'individuo in Porfirio e l'İION погоN stoico," Elenchos: Rivista di studi sul pensiero antico, 21 (2) (2000), pp. 317-328.

37 Aristoteles, Metaphysica, 1040a8-15; this was indicated by J. Barnes (Porphyry, Introduction, p. 153).

38 R. Sorabji, The Philosophy of Commentators, 200-6oo AD: A Sourcebook, vol. 3, Ithaca - New York, 2005, pp. 226-227. 
humans, names can validly be changed according to scripture, ${ }^{39}$ as if the unique qualities were being changed. For example, when the quality of Abram changed he was called Abraham, when Simon's changed he was named Peter, and when Saul's changed, the enemy of Jesus, he was addressed as Paul.

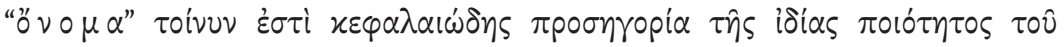

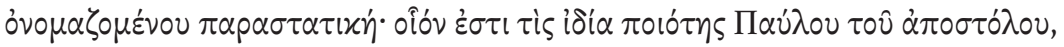

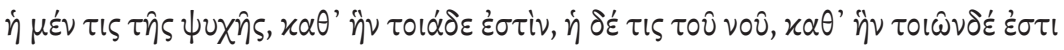

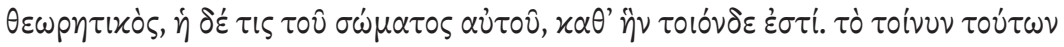

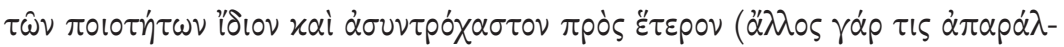

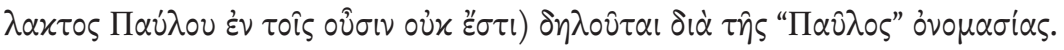

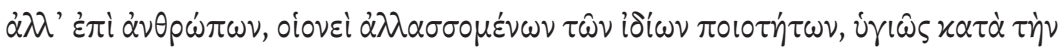

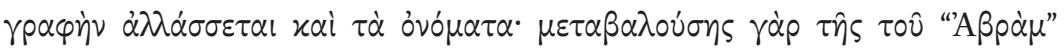

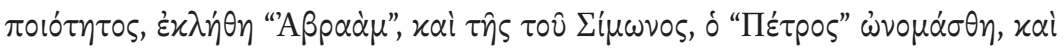

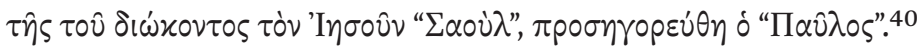

The Stoic inspiration of the passage is obvious. Origen used the Stoic notion of

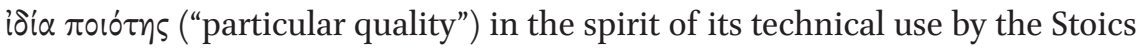
as the unifying principle of multiplicity, bound by the inner unity. ${ }^{41}$ In addition, following the Stoic tradition which we have seen in Diogenes of Babylon, Origen juxtaposed the names and the quality, although he did not follow the

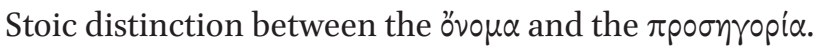

Thus, Origen reproduced the idea of the Stoics, according to which the name of an individual was in accordance with his individual quality, distinguishing him from other people. ${ }^{42}$ As we have noted, according to Chrysippus, two particular qualities corresponding to the proper names could not coexist in the single substance of a given individual. Chrysippus illustrated this point using the example of certain Dion whose special quality was having all his

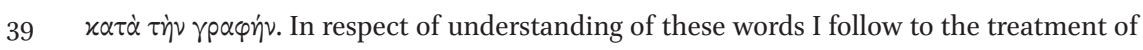
W. A. Curtis' translation of On Prayer (CCEL); in Sorabji's translation: “... in their spelling." PG 11, col. 492bc, trans. Sorabji, The Philosophy of Commentators, 20o-6oo AD: A Sourcebook, vol. 3, p. 227.

41 See Stoicorum Veterum Fragmenta, vol. II, fr. 391.

42 Origen was strongly influenced by the understanding of names in the magical sense, which was quite widespread in the Middle Platonism. See John Dillon, "The Magical Power of Names in Origen and Late Platonism," in: Origeniana Tertia, eds. R. Hanson and H. Crouzel, Rome, 1985, pp. 203-216). Yet here, due to the general Stoic context we need to speak about the influence of the Stoic ontological and semantic doctrine. 
members, and Theon whose special quality was missing a leg. If Dion loses his feet, he would become Theon, while the former Theon would disappear. ${ }^{43}$

This example confirms the fact that the Stoic doctrine postulated unequivocal correspondence between the particular quality and the name of an individual. Origen followed the reasoning similar to that of Chrysippus: the substantial change in the qualities resulted in the change of the name for the individual. In Origen's model, the instrument that safeguarded the self-identity of an individual was the "particular quality" which could also be changed. The difference in the language of Chrysippus and Origen is that speaking about human individuals, Chrysippus spoke about "substances" which had particular qualities, and Origen did not. ${ }^{44}$

43 "Chrysippus $<\ldots>$ in his work On the Growing, creates a freak of the following kind. Hav-

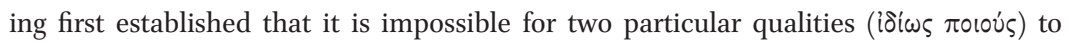
occupy the same substance (ovंбias) jointly, he says: 'For the sake of argument, let one man be thought of as whole-limbed, the other as minus one foot. Let the whole-limbed one be called Dion, the defective one Theon. Then let one of Dion's feet be amputated.' The 'question arises which one of them has perished, and his claim is that Theon is the stronger candidate. These are the words of a paradox-monger rather than of a speaker of truth. For how can it be that Theon, who has had no part chopped off, has been snatched away, while Dion, whose foot has been amputated, has not perished? 'Necessarily', says Chrysippus. 'For Dion, the one whose foot has been cut off, has collapsed into the defective substance of Theon, and two particular qualities cannot occupy the same substrate.

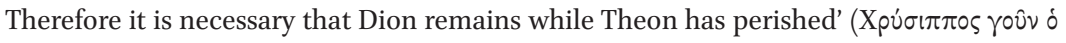

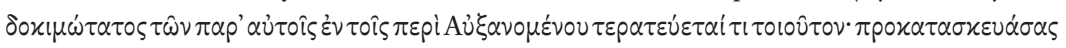

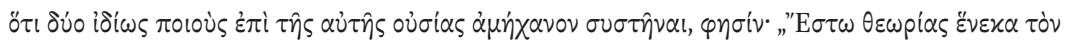

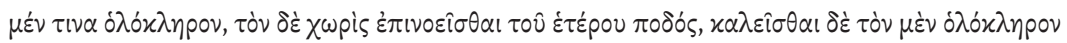

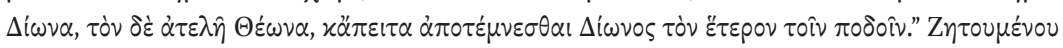

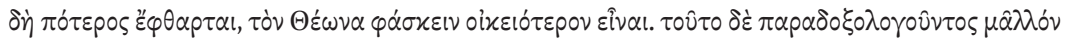

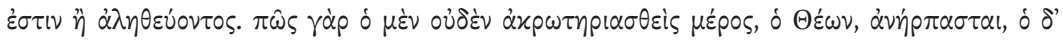

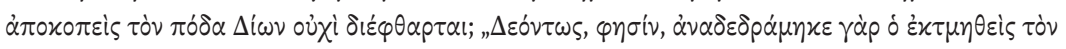

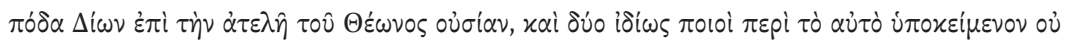

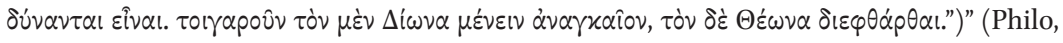
De aeternitate mundi, 48-49 (= Stoicorum Veterum Fragmenta, vol. II, fr. 397), trans. by D. Sedley, in: Sedley, “The Stoic Criterion," pp. 267-268, slightly revised). John Bowin argued that in this case, in his polemics with the Academics Chrysippus challenged exactly the premises of the Treatise on Growth from the comedy of Epicharmus (J. Bowin, "Chrysippus' Puzzle about Identity," Oxford Studies in Ancient Philosophy, 24 (2003), pp. 244-246). In turn, David Sedley has shown that the reasoning of Chrysippus presented by Philo suggested that one-legged Theon was a part of Dion who had all his members, that is, the name of Theon designated the body of Dion minus one Dion's leg (Sedley, "The Stoic Criterion," p. 269).

44 The opponent of Basil Eunomius followed a similar logic, according to which the name uniquely corresponded to the property, that is, to a particular substance (Eunomius did 
It should also be noted that our passage from of the Contra Eunomium by Basil of Caesarea quite clearly shows the Stoic overtones. This is evident when Basil writes about the general substance of people as a material substrate ( $\tau \dot{0}$ i $\lambda$ ixòv i $\pi \circ x \varepsilon i \mu \varepsilon v o v$ ) in addition to the argument about human individuals as carriers of various qualities. The presence of the Stoic overtones in Basil's doctrine of substance was pointed to by R. Hübner. He noted that for the both ontological orders, distinguished by Basil (for the created and the uncreated), Basil used the Stoic model as far as substance was concerned; in the case of the uncreated realm he used the created realm as an analogy. ${ }^{45}$ One can agree with R. Hübner, emphasizing that this was just one of the trends in Basil's doctrine of substance ${ }^{46}$ along with the Aristotelian trend. ${ }^{47}$ However, Hübner

not distinguish between the "substance" and the "property"). In his Apology he argued that the Son and the Father could not be of the same substance since the same substance could not be simultaneously begotten and unbegotten, and if the Son becomes of the same substance as the Father, he would become unbegotten and consequently, the Father would cease to beget, that is, both would lose their properties (Liber Apologeticus, 14; Eunomius, The Extant Works, ed. R. Vaggione, Oxford, 1987, p. 50). Thus, the participation in the substance, according to Eunomius, involved the participation in name (cf. Liber Apologeticus, 9,10-12; Eunomius, The Extant Works, p. 44). However, judging the terminology used by Eunomius, which is quite common, it is unlikely that he might use the Stoic doctrine in this respect (the influence of the Stoic tradition in Eunomius can rather be seen in his doctrine of language, see below).

R. Hübner, Gregor von Nyssa als Verfasser, pp. 478-481. Balás and Robertson also pointed to the Stoic elements in Basil's doctrine of substance, see D. Balás, "The Unity of Human Nature in Basil's and Gregory of Nyssa's Polemics against Eunomius," SP, 14 (1976), pp. $275^{-281}$, here p. 279 and D. Robertson, "Stoic and Aristotelian Notions of Substance in Basil of Caesarea," vc, 52 (1998), pp. 396-406.

46 A. Choufrine disagrees with this statement of R. Hübner arguing that Basil rejects the divisibility of the divine substance (Basil of Caesarea, Contra Eunomium 1,19; PG 29, col. 556a; cf. Epistula, 361; PG 32, col. 1101a), while divisibility is inherent in substance understood as substrate (Choufrine, "The Development of St. Basil's Idea of 'Hypostasis', p. 15). However, one may also argue that divisibility of substrate in Basil's understanding is essentially irrelevant to the divine substance, described by analogy with the substrate (as it was noted by R. Hübner) and for certain purposes - in order to indicate that the divine substance was unknowable and inexpressible in speech (see below).

The formalization of the concept of essence by means of the Aristotelian conceptual

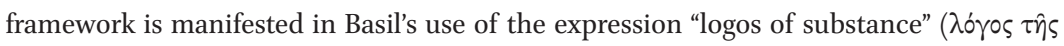

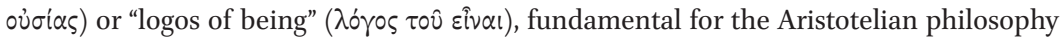
(Contra Eunomium, 1.5, 19; PG 29, col. 520, 556), reflected the unity of the hypostases of the Holy Trinity in substance; whereas for indicating the mode of being for each hypostasis in

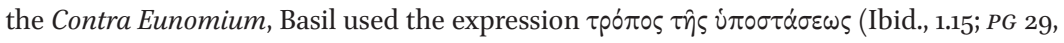
col. 548a), while in the Homily Contra Sabellianos et Arium et Anomoes, Basil used the

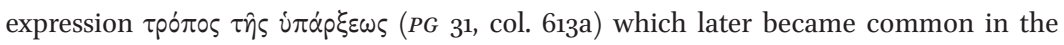


was wrong in claiming that the material substrate ( $\tau \dot{o}$ ì people, mentioned by Basil in the passage under discussion, corresponded to

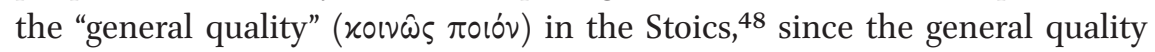
could not have been viewed by the Stoics in the "generic" terms.

Apparently, Hübner was misled by the words of Basil that all humans were made of clay, and it is this clay that Hübner associated with the "general quality." However in this case Basil simply quoted the Book of Job, understanding clay metaphorically as something that indicated the prime matter devoid of quality, and the subject to formation. Basil did not mean that all people were made directly of clay, that is, that clay was really present in each human as a kind of common quality.

Keeping in mind the strategies of Basil, which he pursued in the Contra Eunomium, we may argue that Basil's understanding of substance in our passage as the material substrate is based on one of the understandings of "substance" by the Stoics in the sense of the qualityless substrate, formed by qualities. ${ }^{49} \mathrm{Ba}$ sil needed this concept to convince his readers by analogy in the idea that the divine substance cannot be comprehended in our thought and expressed in speech - similarly to inexpressible and incomprehensible prime matter as opposed to particular qualities accessible to thought. ${ }^{50}$ Basil's identification of "substance," understood in this manner, and "hypostasis" in our passage ${ }^{51}$ only shows that Basil refuted the thesis of Eunomius, using the terminology of his opponent. 52

Byzantine theological language. This expression may go back to the commentators of the logical works of Aristotle (both expressions can be translated as "the mode of existence" or "mode of being"). For the discussion of the balance between the Stoic and Peripatetic elements in Basil's doctrine of substance, see Robertson, "Stoic and Aristotelian Notions of Substance."

48 Hübner, Gregor von Nyssa als Verfasser, S. 476.

49 See I. von Arnim, Stoicorum Veterum Fragmenta, Stuttgart, 1903 [repr. 1964], vol. I, fr. 493; vol. II, fr. 318, 374, 376, 380 .

50 Cf. Contra Eunomium, 2.5 (PG 29, col. $580 \mathrm{oc}$ and 1.12-13, 15; PG 29, cols. 540c-541bc, 548ab).

$51 \quad$ "... None of these is his substance, understood as hypostasis ( $\dot{\eta} \dot{\tau} \pi \dot{\sigma} \sigma \tau \alpha \sigma \iota \varsigma) . "$

$5^{2}$ Cf. the words of Eunomius, which Basil refutes, "... We take it that his hypostasis is the very same as that which is signified by his name, granted that the designation applies

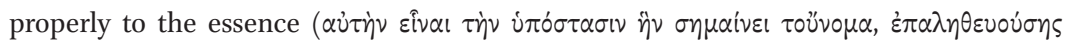

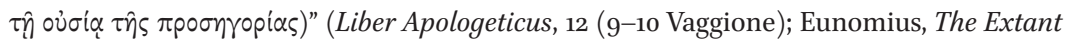
Works, p. 48, slightly revised; for a lengthier citation from Eunomius, see below). Using the term i $\tilde{\sigma}^{\circ} \sigma \tau \alpha \sigma \iota \varsigma$, in the passage Eunomius followed the terminology typical for the Arian movement (and going back to Origen). This terminology described three hypostases of the Trinity (in such a way that the hypostasis of God is infinitely higher than the hypostasis of Christ which, in turn, is infinitely higher than the Spirit); see the corresponding passage in the Thalia of Arius, cited by Athanasius of Alexandria in De Synodis, 15 (PG 26, 
Thus the topic of the "concurrence of properties" in the passage under discussion brings us back to a number of various historical and philosophical contexts. On the one hand, this is the Stoic tradition, and more specifically the physical and ontological perspectives of the Stoic tradition. In this regard, the conceptual system of Basil implied that there was material substrate constituting the substance of all human beings, as well as of the whole of the created world, ${ }^{53}$ and it was "shaped" by the qualities of Peter and Paul. On the other hand, these qualities in the way they are described by Basil do not quite resemble the physical qualities (which can only endow matter with forms). In fact, their purpose as a whole was to provide a narrative, an account of each individual, which, as it was rightly noted by P. Kalligas, ${ }^{54}$ was the novelty of Basil's approach. And in this regard, Basil constantly emphasized the capacity of these properties to be represented in the human mind, ${ }^{55}$ which brings his approach close to that of Porphyry, for whom the properties, individualizing the singularity, possessed an epistemological status.

In addition, the language of Basil brings him closer to Porphyry: for indicat-

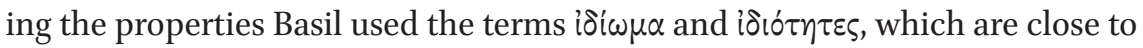

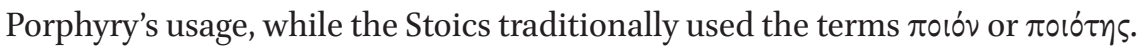
Thus, given the likely interpenetration of Stoic and Neoplatonic traditions in the Late Antiquity in respect to the concurrence of qualities, we may argue that Basil also shows a synthetic position.

This duality in the use of different conceptual systems, namely, the ontological framework and the framework of intellectual comprehension, is also reflected in the functions of the concept of $\chi \alpha \rho \alpha x \tau \eta n p$ in our passage from the Contra Eunomius of Basil: the totality of properties behind each name, which arise in our mind when we hear the name, forms the representation / $\chi \alpha p \alpha x \tau \eta \dot{p} \rho$ of a person. On the one hand, the subject of $\chi \alpha \rho \alpha \varkappa \tau \dot{\eta} p /$ representa-

col. 708a). Thus, there is no reason to contrast this passage of Basil with the theological language of the so-called Letter 38 of Gregory of Nyssa, as A. Choufrine does. Cf. “... [in the Letter 38] the proper names, although they do not signify substance - the point in which the author of the letter agrees with Basil - do (contrary to what Basil says [in his Contra Eunomium, 2.4 (PG 29, col. 577C-580B)]) signify hypostases)" (Choufrine, "The Development of St. Basil's Idea of 'Hypostasis," p. 23).

Contra Eunomium, 2,24; PG 29, col. 628c, as well as Balás, "The Unity of Human Nature," p. 278.

54 P. Kalligas, "Basil of Caesarea on the Semantics of Proper Names," Byzantine Philosophy and Its Ancient Sources, ed. K. Ierodiakonou, Oxford, 2002, pp. 31-48, here p. 45.

55 Cf. 'So whenever we hear 'Peter,' the name does not cause us to think of his substance

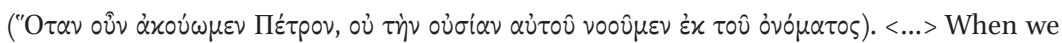

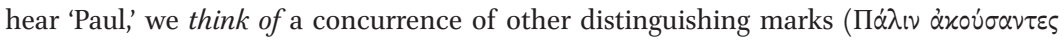

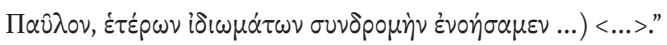


tion, pointing to a certain unity which occurs in the human soul from a variety of thoughts or representations about something, ${ }^{56}$ appears already in the first book of the Contra Eunomium ${ }^{57}$ and can also be seen in the passage under discussion. On the other hand, another function of this concept points to the individuality of a person, to his destiny, to that what "happens" to him, ${ }^{58}$ and this function reflects how it would be used in Byzantium in the later times.

One may argue that the topic of the material substance in Basil's writings was treated from the viewpoints of both Platonic and Stoic traditions. The Platonic tendency in viewing material substance by Basil is manifested in the widely discussed passage from his Hexaemeron, where Basil speaks of material substance as of the substrate, composed by and limited by the totality of the intellegible qualities. ${ }^{59}$ This topic was also touched upon by Basil's brother,

56 The concept of $\chi \alpha \rho \alpha \varkappa \tau \eta \dot{\rho}$, understood as a kind of imprint or impression, arising in the soul from an aggregate of "thoughts" on a certain object, has Stoic connotations. According to Zeno, Cleanthes, and some other Stoics, the impression ( $\left.\varphi \alpha v \tau \alpha \sigma^{\prime} \alpha\right)$ is the "imprint ( $\tau \dot{\tau} \pi \omega \sigma \iota)$ in the soul," similar to an imprint which originates from seal on wax (Stoicorum Veterum Fragmenta, vol. I, fr. 58; vol. II, fr. 53, 55-60). When Philo speaks about this imprint, he uses the word $\chi \alpha \rho \alpha \varkappa \tau \dot{p} \rho$ and notes that such imprints are perceived by the mind and are stored in memory (Philo, Quod deus sit immutabilis, 43). I. von Arnim placed this fragment of Philo in his collection of Stoic fragments (Stoicorum Veterum Fragmenta, vol. II, fr. 458), however, Philo's language is already the result of the assimilation of the Stoic ideas. In our case, the possible impact on the language of Basil was made by Philo rather than the Stoics. We should note that both according to the Stoics and to Philo the imprint on the soul might originate only from the objects of sense perception.

"Now some of the names applied to God are indicative of what is present to God; others, on the contrary, of what is not present. From these two something like an impression ( $\left.\chi \alpha p \alpha \chi \tau^{\prime} p\right)$ of God is made in us, namely, from the denial of what is incongruous with him

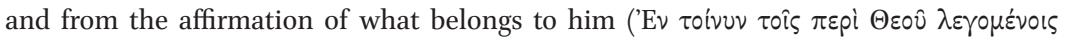

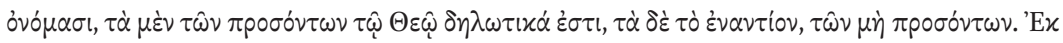

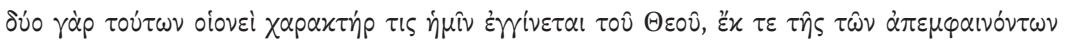

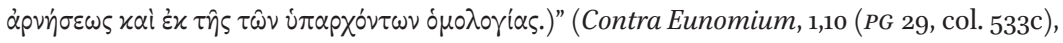
trans. by DelCogliano and Radde-Gallwitz: St. Basil of Caesarea, Against Eunomius, p. 105). If we take into account this aspect, the hypothesis of D. Robertson seems to be not very convincing. According to D. Robertson, Basil was influenced by the Syntax of Apollonius Dyscolus where the concept of $\chi \alpha \rho \alpha \varkappa \tau \eta \dot{p}$ was associated with the name of the subject of discourse, inflected for cases for avoiding homonymy (Robertson, "A Patristic Theory", p. 19).

59 "If we were to wish to discover the essence of each of the beings which are offered for our contemplation, or come under our senses, we should be drawn away into long digressions, and the solution of the problem would require more words than I possess, to exam-

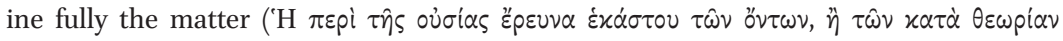

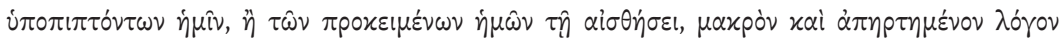

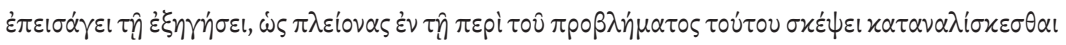


Gregory of Nyssa in his Hexaemeron ${ }^{60}$ and in the treatises On the soul and the resurrection ${ }^{61}$ and On the making of man ${ }^{62}$ where Gregory emphasized that any material thing was composed of intelligible qualities as if of ideas. A. Armstrong suggested that the position, according to which the material substrate was a set of qualities, was adopted by Basil as a result of reading the Enneads of Plotinus. Armstrong argues that Basil must have borrowed his position from the unknown Platonists who commented upon Timaeus $52 \mathrm{a} 8$ and whom Plotinus criticized in the Enneads 2.4.11.10-13. ${ }^{63}$ However, P. O'Cleirigh quite convincingly suggested ${ }^{64}$ that Basil here builds upon the idea expressed in the 4 th Book of the De Principiis of Origen. ${ }^{65}$

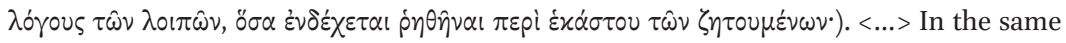
way, as concerns the earth, let us resolve not to torment ourselves by trying to find out its essence, not to tire our reason by seeking for the substance which it conceals. Do not let us seek for any nature devoid of qualities by the conditions of its existence, but let us know that all the phenomena with which we see it clothed regard the conditions of its existence and complete its essence. Try to take away by reason each of the qualities it possesses, and you will arrive at nothing. Take away black, cold, weight, density, the qualities which concern taste, in one word all these which we see in it, and the substrate vanishes

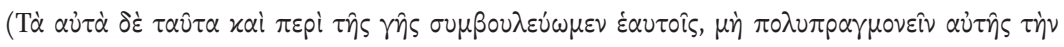

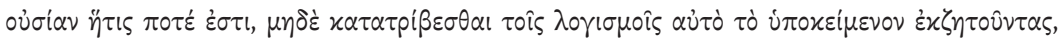

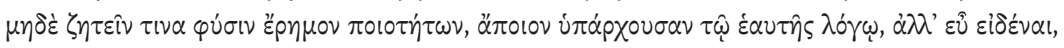

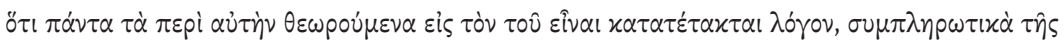

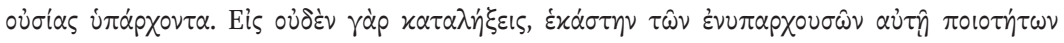

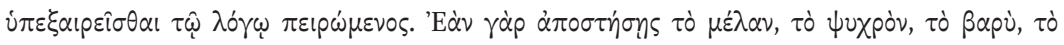

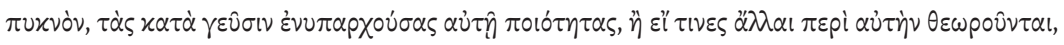

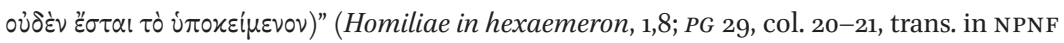
II-8, slightly revised). I do not agree with the opinion of Johannes Zachhuber (J. Zachhuber, "Stoic Substance, Non-Existent Matter? Some Passages in Basil of Caesarea Reconsidered," $S P, 41$ (2006), pp. 425-431) that in our fragment Basil had in mind not that taking away all the qualities from the material substance of earth would leave "nothing," but that the search for the substance of earth was a futile occupation.

60 Gregory of Nyssa, Apologia in hexaemeron; $P G$ 44, col. $69 \mathrm{bc}$.

61 Idem, De anima et resurrectione; $P G$ 46, col. 124bd.

62 Idem, De opificio hominis, 24; PG 44, cols. 212d-213b.

63 A. Armstrong, "The Theory of the Non-Existence of Matter in Plotinos and the Cappadocians," $S P, 5$ (1962), pp. 427-429, here p. 427.

64 P. O'Cleirigh, "Prime Matter in Origen's World Picture," $S P, 16$ (1985), pp. 260-263, here 262-263.

65 Origen, De Principiis, 4.7.34: Origène, Traité des principes, vol. 3, eds. H. Crouzel, M. Simonetti (sc, 268), Paris, 1980, pp. 416-418. It follows from Basil's use of Origen's passage that while borrowing the ideas from the De Principiis, Basil polemicized with the notion of the uncreated matter. 
It is possible to agree with R. Sorabji on the Platonic inspiration behind Basil's understanding of material substance as a substrate composed of the totality of intelligible qualities, developed by Gregory of Nyssa as a part of his theory on matter as the totality of immaterial ideas. ${ }^{66}$ The understanding of the sensible substance in line with the Stoic tradition exactly implies that substance cannot be exhausted by qualities only, since after the removal of intelligible qualities there always remained a certain residue, the qualitiless substrate, which cannot be comprehended by the mind and expressed in speech. Thus, in our fragment of the Contra Eunomium as well as in other places of this treatise of Basil ${ }^{67}$ we may find the understanding of the material substance, based on the Stoic, and not Platonic philosophical tradition.

This conclusion can be correlated to the fact that Basil, unlike Gregory, used

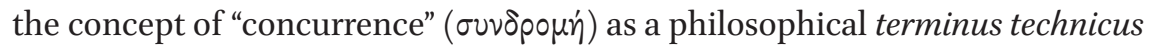
exclusively when he discussed human individuals, but did not use it for inanimate material things. Yet, if in the Platonic tradition the concept of "concurrence" or "aggregation" of qualities was used indiscriminately in relation to human individuals or inanimate material objects, the Stoic philosophical tradition developed an understanding of the process of individuation through the concurrence of properties, applicable only to the human individuals. Thus, Basil's use of the concept may also indicate the Stoic background.

When Gregory of Nyssa addressed the topic of the concurrence of properties, unlike Basil he did not distinguish between the human individuals and inanimate objects quite in the spirit of the Platonic tradition. Gregory, being inclined to Platonism, might have not accept the ideas which Basil received from the physical and ontological tradition of the Stoic doctrine, including Basil's emphasis on understanding the substance of the created beings as the material substrate. As D. Balás showed, ${ }^{68}$ when Gregory of Nyssa commented upon our fragment of Basil in his own Contra Eunomium, he emphasized the Platonic (with some reservations) understanding of the human nature as a generic substance common to all human beings and existing in the individuals, as opposed to Basil's emphasis on the understanding of a single nature of people in terms of the common substrate. When Gregory cited Basil's passage

66 R. Sorabji, "Gregory of Nyssa: The Origins of Idealism," in: idem, Time, Creation and the Continuum. Theories in Antiquity and the Early Middle Ages, London, 1988, pp. 292-293. Richard Sorabji points to an Enneades of Plotinus (6.3.8) and to Simplicius' paraphrase of Porphyry's ideas in In Aristotelis physicorum libros commentaria (230.34-231.7) being the Platonic parallels to these ideas. In general, R. Sorabji correlated the doctrine of the Cappadocian Fathers with the idealist philosophical position of G. Berkeley.

67 Cf. Contra Eunomium, 1,12; PG 29, col. 540c, 541bc.

68 Balás, “The Unity of Human Nature," pp. 278-279. 
under discussion and reached the words, "now by 'substance' I mean the mate-

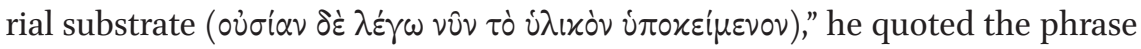
in the way opposite to the original, "now by 'substance' I mean not the material substrate ( lar attention to this fact, assuming that Gregory corrected the passage which did not fit his views and the needs of his polemics with Eunomius.

P. Kalligas did not take into account the background of Stoic physics in our passage of Basil and identified the philosophical background of the passage with the Platonic tradition. ${ }^{70}$ This allowed him to speak of the extreme nominalist leanings of Basil, comparable to the nominalism of William of Ockham. ${ }^{71}$ We may agree that the discussed conceptual framework of Basil does seem nominalist in some respect, exactly in Ockham's sense, that is, in the sense that for building it just like Ockham Basil needed to establish the hierarchy of genera and species. However, Basil's emphasis on the physical realism, associated with his use of Stoic philosophical tradition makes it difficult to ascribe nominalism to Basil in some other more normative sense, when it is believed that general concepts do not correspond to the objects in reality.

At this point we need to put together the main points of Basil's polemical position in the passage under discussion. For doing that, we should take a closer look to the passage from the Apology of Eunomius, which Basil of Caesarea attempted to refute in the passage:

As for showing that the Son too is one, being only-begotten, we could rid ourselves of all care and trouble in that regard simply by quoting the words of the saints in which they proclaim the Son to be both 'offspring' and 'thing made', since by distinguishing the names they show the

69 Gregorius Nyssenus, Contra Eunomium, 3,5,22,7-8: Gregorii Nysseni Opera, ed. W. Jaeger, vol. 2, Leiden, 196o, p. 168.

70 Kalligas, "Basil of Caesaria," pp. 46-47; the articles of Lucian Turcescu on the Letter 38 of Gregory of Nyssa show the same position, see L. Turcescu, "Person' versus 'Individual,' and Other Modern Misreadings of Gregory of Nyssa," Modern Theology, 18 (2002), pp. 527-539, here p. 530; idem, "The Concept of Divine Persons in Gregory of Nyssa's to His Brothers Peter, on the Difference between Ousia and Hypostasis," Greek Orthodox Theological Review, 42 (1997), pp. 63-82, here 74-77.

“... We are led to the conclusion that Basil, in his attempt to rebut Eunomius' naturalist theory of names, extended the ontological theory we find in Porphyry, but which has its roots in the sceptical Academy, towards an extreme nominalist position as concerns the semantics of proper names - a position which stood as the most complete and the most seductive such contribution to philosophical thought, at least until the time of William of Ockham” (Kalligas, "Basil of Caesaria," p. 47). 
difference in essence as well. $<\ldots>$ We call the Son 'offspring', therefore, in accordance with the teaching of the Scriptures. ${ }^{72}$ We do not understand his essence to be one thing and the meaning of the word which designates it to be something else. Rather, we take it that his hypostasis is the very same as that which is signified by his name, granted that the designation applies properly to the essence.

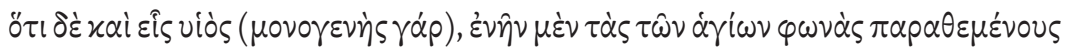

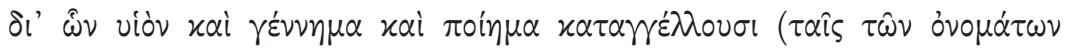

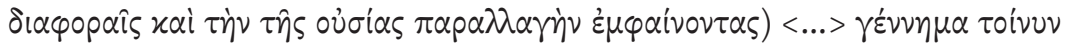

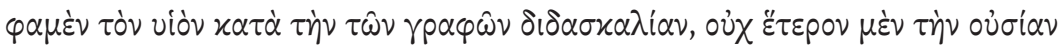

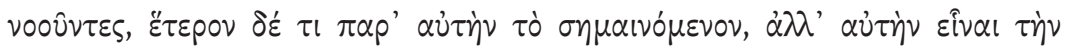

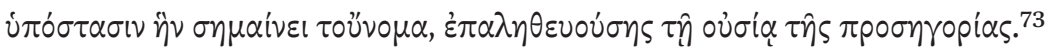

We should recall that Eunomius put emphasis on the difference between God and Christ (the Son) in substance, deriving this, among other things, from the fact that their true names had different and oppositing meaning. The names,

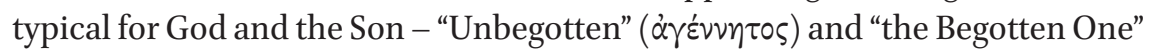
$\left(\gamma^{\prime} \nu \nu \eta \mu \alpha\right)$ - for Eunomius were not the names understood in the magical sense similarly to the Iamblichian names of the gods, as his position is often misunderstood. ${ }^{74}$ These names reflect the notions, most appropriate to God and the Son according to the true understanding of their natures, since God has no cause for his existence, while the Son does. ${ }^{75}$

The difference in the Eunomian understanding of the names of the Holy Trinity from the magical understanding which we may see, for example, in Origen and Iamblichus, is that the conclusion on the importance of the formal

72 Prov. 8:22; cf. 1 Cor. 1:24.

73 Liber Apologeticus, 12,1-4, 6-9, trans. by R. Vaggione, in: Eunomius, The Extant Works, pp. 46-48, slightly revised. Here the fragment of the Apology is cited in a lengthier form than it was cited by Basil is his treatise (Contra Eunomium, 2,1; PG 29, col. 573), since Basil's refutation is built on a wider text of Eunomius than the passage cited.

Jean Daniélou based his conclusions on this supposition when he tried to prove the influence of the Cratylus exegesis of the Iamblichian school on the theory of names of Eunomius (J. Daniélou, "Eunome l'arien et l'exégèse néoplatonicienne du Cratyle," Revues des études grecques, 69 (1956), pp. 412-432). See the criticism of such an understanding in J. Rist, "Basil's 'Neoplatonism': Its Background and Nature," in: Basil of Caesarea: Christian, Humanist, Ascetic, ed. P. Fedwick, Toronto, 1981, pp. 185-188; D. Biriukov, "Strategies of Naming in Polemic between Eunomius and Basil of Caesarea in the Context of the Philosophical Tradition of Antiquity," Scr, 4 (2008), pp. 103-121, here p. 119. 
aspect of naming, that is, of name's sound is derived from the principle of the natural relationship between names and things as opposed to conventional relationship. At the same time, the meaning of name do not play any significant role both for Origen and for Iamblichus as far as Iamblichus' teaching on theurgy is concerned. ${ }^{76}$ This is reflected in the fact that both Origen and Iamblichus assumed the critical importance of some sacred language; they did not consider it necessary to understand the meaning of the words in this language. Thus, Origen emphasized the power of the Jewish names of God, denying any validity of the name if it is translated into another language, ${ }^{77}$ and Iamblichus insisted that the names of Eastern gods should be preferred. ${ }^{78}$ Eunomius, however, does not show such magical understanding of names. On the contrary, the crucial names for the Eunomian doctrine of the Father and the Son have unambiguous meaning: for example, the name "Unbegotten" contains the meaning, indicating the specific charactery of the divine existence as opposed to the created existence. The meaning is defined by the fact that Eunomius constructs the names on the basis of his understanding of the named entities; he extensively demonstrates on the basis of his pre-defined principles why the true name of God was "Unbegotten," and the true name of the Son was "the Begotten One."

In the above passage, Eunomius uses the arguments "from names," accord-

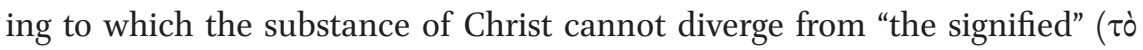

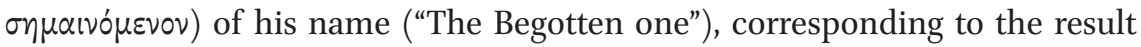
of the mental comphenension of his substance. As its premise, the Eunomian argument "from names" has the idea about the wise men who know the nature of things as well as the names which fit things and correspond to their nature. This concept was widespread in Antiquity and in the Hellenistic pe$\operatorname{riod}^{79}$ and is reflected in the Bible. ${ }^{80} \mathrm{~T}$. Kopecek believes that this case shows the impact of Middle Platonic ideas on Eunomius, since this position is most

${ }_{7} 6$ On Iamblichus in that respect, $\mathrm{cf}$. G. Shaw, Theurgy and the Soul. The Neoplatonism of Iamblichus, University Park, PA, 1995, p. 111.

77 Origen, Contra Celsum, 5.12.45; PG 11, col. 1249c, 1253.

78 Iamblicus, De mysteriis, $7 \cdot 5$.

79 With regard to the belief in the wise establisher of names in Antiquity, see Plato, Cratylus, 387d4-5; Alcinous, Epitome, 6,10; Ammonius, In Aristotelis librum de interpretatione commentarius, 1,3, 34-4ob. It is noteworthy that many authors of Antiquity advanced the view on names as having been established by God, without speaking about names' correspondence to the named objects' nature, but implying it, see Cicero, Tusculanae disputationes, 25.62, De republica, 3.2; Origenes, Contra Celsum, 5.30; Philo, Legum allegoriae, 2.14-15 (Mondésert).

$80 \quad$ Gen. 2:20. 
clearly expressed in Albinus. ${ }^{81}$ Yet, in our view, the Stoic terminology used by Eunomius speaks rather about the impact of the Stoic conceptual fremework.

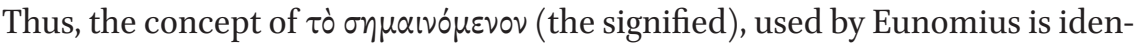
tical to the notion of the $\lambda \varepsilon \kappa \tau o ́ v$, fundamental to the Stoic system.

The introduction of this concept by the Stoics led to the deeper understanding of language and linguistic processes in comparison to Aristotle. In fact, Aristotle's three-partite structure of language: the signifying (sounds) - the representation (thought) - the object, ${ }^{82}$ thanks to the concept of "meaning" in the Stoics, was transformed into a four-partite structure: the signifying (sounds) - the signified (semantic objectivity, revealed in the word, or the lekton) - the representation (thought) - the object. ${ }^{83}$ The concept of the "signified" which for the Stoics was an intermediary between the word and the thing 84 united the thought and the word, which were disconnected in Aristotle. ${ }^{85}$ This concept, in turn, became very suitable for the development of the possibility to select and to know the correct names of the things, the nature of which is known. It was popular in the Hellenistic era, but is found among the Stoics, ${ }^{86}$

81 Albinus (Alcinous), Epitome, 6,10-11; Kopecek, A History of Neo-Arianism, vol. 2, pp. 321, 329-332.

82 Aristotle, De interpretatione, 1,3.

83 See Sextus Empiricus, Adversus mathematicos, 8,11-12. In the passage Sextus mentions but does not specifically elaborate upon the third member of the structure, that is, the thought. Specifically on the "signified," cf.: "signification is the actual state of affairs revealed by an utterance, and which we apprehend as it subsists in accordance with our thought, whereas it is not understood by those whose language is different although they hear the utterance (

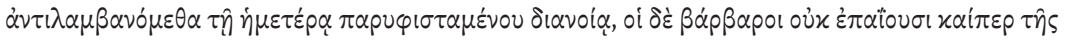

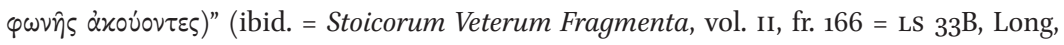
Sedley, The Hellenistic Philosophers, vol. 2, pp. 195-196). This means that "the signified" differs from the thought in that the thought is not a reality belonging to the language, whereas "the signified" belongs both to the reality of thought and to the reality of language (cf.: "... whereas it is not understood by those whose language is different although they hear the utterance").

84 Stoicorum Veterum Fragmenta, vol. II, fr. 168.

85 The doctrine of Aristotle entailed the isomorphism not between the word and the thought, but between the thing and the thought (Lloyd, "Grammar and Metaphysics," p. 65).

86 See the comments of Long and Sedley on the fragment of Diogenes Laertius, 7.83 ( $\mathrm{LS}_{31 \mathrm{C}}$ ): Long, Sedley, The Hellenistic Philosophers, vol. 2, pp. 187-188, as well as the article: A. Long, "Stoic Linguistics, Plato's Cratylus, and Augustine's De dialectica," in: Language and Learning. Philosophy of Language in the Hellenistic Age, eds. D. Frede, B. Inwood, Toronto, 2005, pp. $36-55$. 
and later, as we have seen, in Eunomius, exactly in relation to the notion of $\tau$ '̀

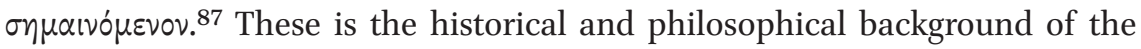
teaching of Eunomius on the mandatory relationship between the name and the substance of the Son. ${ }^{88}$

Accordingly, in the passage under discussion Basil refuted Eunomius' approach to naming which required the establishment of a rigid connection between the name, the meaning, the thought, and the object, and shifted from Eunomian line of argumentation, involving the use of the appellative name, that is, referring the reader to a particular predefined meaning ("The Unbegotten," "The Begotten One"), to the realm of the proper nouns ("Peter," "Paul") the lexical items, by definition not allowing the use of the concept of the predefined meaning. Avoiding the concept of "meaning," Basil actively used the terminology that refered the reader to mental processes.

87 The fact that Eunomius understood language in terms of the fourfold paradigm which included the notion of "meaning," is revealed in the following passage of the Apology: “... we need not try to conform meanings to names exactly or try to distinguish those of differing expressions, but must rather direct our attention to the concepts inherent in the underlying objects and accommodate the name accordingly (for the natures of objects are not naturally consequent on the verbal expressions: rather, the force of the names is

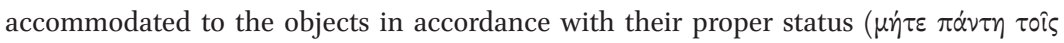

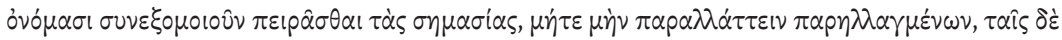

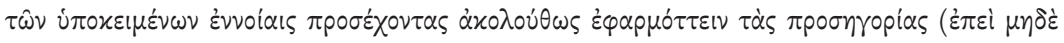

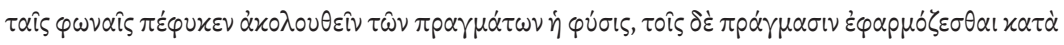

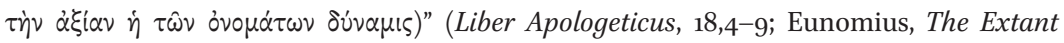
Works, pp. 54-57). The importance of the concept of "meaning" for Eunomius is also revealed in the passage from the Contra Eunomium of Gregory of Nyssa, which is dedicated to the refutation of the Eunomius' attempts to refute the passage of Basil discussed in this study: "<...> I do not like to insert in my own work the nauseous stuff our rhetorician utters, or to display his ignorance and folly to contempt in the midst of my own arguments. He goes on with a sort of eulogy upon the class of significant words which express

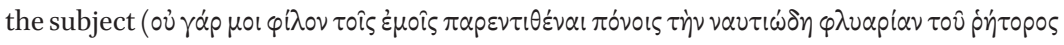

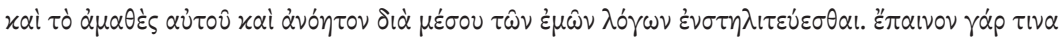

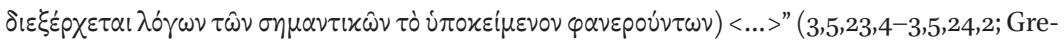
gorii Nysseni Opera, ed. W. Jaeger, vol. 2, p. 168). Notably, the fact that Eunomius did not identify the linguistic reality with the ontological reality (the tendency of which is embedded in the "magical" understanding of language), follows from his words, "God, whether these sounds are silent, sounding, or have even come into existence, and before anything

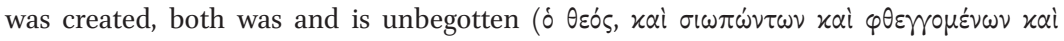

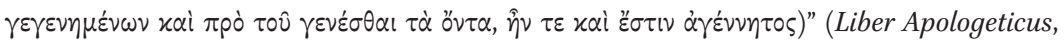
8,5-7; Eunomius, The Extant Works, pp. 42-43). In general see: Biriukov, "Strategies of Naming." 
Now we can summarize our argument. For refuting the position, presented in the Apology of Eunomius, Basil shifted the scope from the realm of theology to the realm of the material world. For doing that he used the conceptual framework of the Stoic physics, accepting the notion of the human substance as general material substrate, formed by the qualities, but not exhausted by them, as opposed to the understanding of the material nature in the Platonic framework, used by Basil in his other works. Basil needed it for putting emphasis on the fact that substance as such, both created and uncreated, was unknowable and could not be expressed in speech, while only qualities (properties) could be known and expressed. Following one of the aspects of the Stoic doctrine or Alexandrian grammarians who developed this topic, as well as the passage from Origen's De oratione, Basil highlighted and developed the point that names corresponded not to substances as Eunomius claimed, but to the qualities.

We should note that when Basil says that qualities correspond to the proper names, while the substance common for all humans is the material substrate, he uses the elements of the Stoic doctrine only as a tool for illustrating his own position. When Basil resorted to Stoic conceptual tools, he did not adopt the Stoic system in its entirety, since it was common for the Stoic doctrine not only to perceive substance as qualitiless general substrate, but also to have the notion of a singular substance which is a "part" of the underlying substrate. ${ }^{89}$ The use of the Stoic concept of singular substances which are individualized by specific quality accessible for knowledge, would have rather been in favor of the position of Eunomius. Thus in the fragment under discussion Basil focuses on substance as qualitiless substrate and on an individual as described by the aggregation of qualities, but does not mention considering human individuals as singular substances.

While for proving the unequivocal correspondence of name and substance Eunomius used the fourfold division of the language, going back to the Stoics, the position of Basil in terms of the understanding the language can be described as close to the Aristotelian. Indeed, there is nothing in his argument that would indicate the concept of "meaning;" it involved the three-part structure: the word (the name) - the representation (the thought) - the object, typical for the Aristotelian position. To avoid the possibility of the unequivocal indication of the individual, which would be the evidence in favor of the Eunomian

89 On "substance," understood by the Stoics as a singular substance, see Philo, De aeternitate mundi, 48-49 = Stoicorum Veterum Fragmenta, vol. II, fr. 397. On the singular substance as a part of substance-prime matter among the Stoics, see ibid., vol. I, fr. $87=$ vol. II, fr. 316 . 
argument, Basil had to abandon the Stoic notion of a special substantial quality of a human being, typical for Origen (whom Basil used in support of his argument), as well as Origen's idea, consistent with the philosophical position of the Stoics, that the change in a specific quality of the Apostles and other Biblical characters would entail the change of their names. ${ }^{90}$ Thus, probably for avoiding this thorny issue, Basil did not mention the fact of changing Apostle Paul's name.

The rejection of the Stoic notion of the particular quality entailed the disregard for the very division of qualities into the general and the particular, and in linguistic terms the disregard for the distinction between the ovo $v \alpha$ and the $\pi$ poonropia, which corresponded to these types of qualities according to the Stoics. ${ }^{91}$ Instead, in the process of individualizing a person Basil lists a number of different qualities and unlike the Stoics does not distinguish between them according to types, bringing them into unity through the principle of concur-

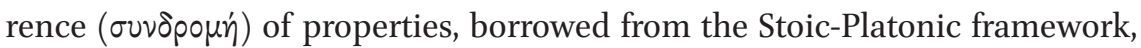
that is, through the listing the qualities. The notion of $\chi \alpha \rho \alpha \varkappa \tau \dot{p} \rho$ played the role of the "particular quality" in Basil. That notion, on the one hand, had psychological connotations: it pointed to a set of representations concerning human individuals - Apostles Peter and Paul (in this case, an echo of ancient philosophical tradition); on the other hand this concept pointed to the individuality of each person and to the specific character of his life, which later becomes a hotly debated topic in Byzantium in the polemics between the Iconophiles and the Iconoclasts.

The qualities, listed by Basil, included both general and relative properties as well as those properties which uniquely placed the person within the se-

90 See above, Origenes, De oratione, 24; PG 11, col. 492bc.

91 We would like to draw attention to a strange phrase of Basil in our fragment, " $<\ldots>$ the

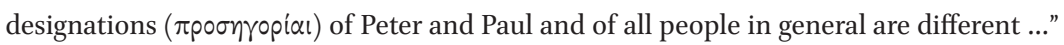
There are many more people than their names, and the difficulties caused by homonymy (that is, in this case by the same names of people) troubled the minds of philosophers already in the time of Democritus (see E. Heitsch, Die Entdeckung der Homonymie, Mainz - Wiesbaden, 1972). Later the problems of homonymy were dealt with in the Greek textbooks on grammar, and Basil had to be aware of this. In the view of the subsequent phrase, "... the designations ( $\alpha i$ i poonropial) do not signify the substances, but rather the distinctive features that characterize the individual," it could mean that Basil was referring to the fact that the sets of properties, but not the names (ovo $\mu \alpha$ ), were different for each person, and these sets were specified by the concept of $\pi$ poonropi $\alpha$. However, if we look at Basil's use of terms in the entire passage, we may see that he used ovo $\mu \alpha$ and

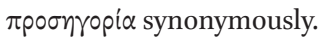


quence of the events of his life. ${ }^{92}$ The passage of Contra Eunomium by Basil of Caesarea is the richest among the cited fragments of various ancient authors, which describe an individual human through the concurrence of properties. In addition to the general properties and the properties of relationships, according to Basil, a person was defined through the full range of what "happened" to him, that is, through his personal history. ${ }^{93}$

Basil's reinterpretation of the principle of the "concurrence of properties," expressed in the outward "unfolding" of properties, can be compared to the

92 The fact that Basil also presented a human individual by means of general properties, points to the problems with the argument of Ch. Yannaras who on the basis of the Cappadocian Fathers developed an understanding of "personhood" which he correlated with hypostasis as that which was opposed to commonness and universality, typical for the notion of "substance." Consequently, according to Yannaras, "personality" or "person" is that which cannot be described by any general qualities which the person possesses $(\mathrm{Ch}$. Yannaras, Person und Eros. Eine Gegenüberstellung der Ontologie der griechischen Kirchenväter und der Existenzphilosophie des Westens, Göttingen, 1982, S. 24-26).

93 Interestingly, this approach of Basil was carried on by the last Iconoclastic Patriarch John the Grammarian (837-843) who challenged the epistemological position of the Iconophiles on the basis of contextual and narrative identification of name's denotation. As Vladimir Baranov pointed out, in one of the three surviving fragments, Patriarch John relied upon our passage of Basil (В. Баранов, "К вопросу об экзегезе святоотеческого текста по триадологической проблематике в иконоборческих спорах" [V. Baranov, "Towards the issue of Trinitarian textual exegesis in the iconoclastic controversy"], in: $C_{8}$. Троица преп. Андрея Рублева в свете православного апофатизма. 18 ноября 2005 2. Иконоборчество: вчера и сегодня. 22 сентября 2006 г. Материалы конферениий [The Holy Trinity of St. Andrei Rublev in the light of Orthodox apophaticism. November 15, 2005. Iconoclasm: Yesterday and today. September 22, 2006. Materials of conferences], SaintPetersburg, 2007, pp. 127-143, here p. 131 (in Russian)). The fragment of Patriarch John the Grammarian runs as follows: "It is impossible to characterise a concrete man by a concept unless with an explanation through words, by means of which one can comprehend and define each being. For the proper accidents of a concrete being by which it has been separated from those belonging to the same species and, in another manner, by which it is communicated to those [who belong to different species], do not contribute in any manner and in any aspect to the perception of sight. For one cannot derive one's race or mark one's country, the certain kind of profession one spends time on, the sort of company one keeps, and the rest of the forms of conduct are not known except by means of words, whereas it is impossible to truly distinguish a certain individual by means of some images" (trans. by V. Baranov in his "Amphilochia 231 of Patriarch Photius as a Possible Source on the Christology of the Byzantine Iconoclasts," SP, 68 (2013), pp. 371-379, here p. 376; see the Greek text in J. Gouillard, "Fragments inédits d'un antirrétique de Jean le Grammarien," RÉB, 24 (1966), pp. 171-181, here pp. 173-174). 
topic of the concurrence of properties in the so-called Letter 38 of Gregory of Nyssa:

Since, then, the Holy Spirit, from whom the entire supply of blessings gushes forth to creation, is united with the Son and with Him is inseparably produced. He has His being attached to the Father as a cause, from whom indeed He proceeds. He has this distinguishing note characteristic of His person, that He is produced after the Son and with Him and that He has His subsistence from the Father. As for the Son, who through Himself and with Himself makes known the Spirit which proceeds from the Father, and who shines forth as the only-begotten from the unbegotten light, He in the matter of the individual tokens which distinguish Him has nothing in common with the Father or with the Holy Spirit, but alone is recognized by the note just named. <...> But perhaps someone thinks that the doctrine of the person here presented does not agree with the conception in the writings of the apostle, where he ${ }^{94}$ says that the Lord is the brightness of His glory and the character ( $\left.\chi \alpha \rho \alpha \tau \eta^{\prime} \rho\right)$ of His person. For if we have taught that person is the concurrence of the individual

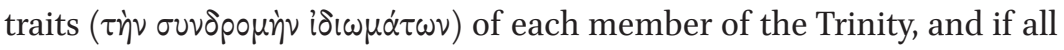
agree, as in the case of the Father, that that trait which is individually observed is something whereby that member alone is recognized, and if in the same way we hold the like belief about the Only-begotten also; how then does it happen that the Scriptures in the passage quoted testify to the term "person" for the Father alone, and speak of the Son as the form "of his person" or "hypostasis," as being characterized, that is, not by His own proper distinguishing notes but by those of the Father ? <...> He who gazes intently with his soul's eyes upon the "character" of the Only-begotten at the same time becomes keenly aware of the "hypostasis" or person of the Father, their recognized individuality not being transferred from one to the other nor yet intermingled, so that we could falsely ascribe either begottenness to the Father or unbegottenness to the Son, but that, if we should disunite the one from the other - an impossible thing - we should apprehend alone by itself the one remaining. For in naming the Son it is impossible not to be keenly aware of the Father also, the appellation "Son" implicitly connoting the Father as well. ${ }^{95}$

$94 \quad$ Cf. Heb. 1:3.

95 Epist. 38.4, 6-7; PG 32, col. 329c, 336c-337a, 337d-340a; trans. by R. J. Deferrari in: Saint Basil, The Letters, vol. 1, London - Cambridge, 1926, pp. 207, 219, 223, slightly revised. 
By using the concept of the concurrence of properties, the author of the Letter pointed to the need of relating each hypostasis with other hypostases, which implied the indivisibility of the Persons of the Holy Trinity. Their joint existence became to be later called the "perichoresis" of hypostases. 